\title{
ATTITUDE OF SECONDARY SCHOOL TEACHERS TOWARDS THE TEACHING OF SEX EDUCATION IN OSOGBO LOCAL GOVERNMENT AREA OF OSUN STATE
}

\section{Alexander Olushola lyekolo}

Department of Social Sciences Education, Faculty of Education, University of llorin, Nigeria

email:

iyekoloo2020@yahoo.com

\section{Kata Kunci:}

Sikap

Sex

Pendidikan seksual

\section{Keywords:}

Attitude

Sex

Sex Education

\begin{abstract}
Abstrak
Studi tentang sikap guru sekolah menengah terhadap pengajaran pendidikan seks, di Osogbo, populasi sasaran terdiri dari semua sekolah menengah di Wilayah Pemerintah Daerah Osogbo negara bagian Osun. Sepuluh sekolah menengah dipilih secara acak dan 20 guru dipilih secara acak dari masing-masing sekolah yang dijadikan sampel sebagai responden. Kuesioner berjudul "Sikap Guru Sekolah Menengah Terhadap Pengajaran Pendidikan Seks (ASSTTTSE)", dengan sifat psikometrik validitas isi dan indeks reliabilitas 0,8I. persentase-test dan Analisis varians (ANOVA) metode statistik yang digunakan dalam menganalisis data yang dikumpulkan. pada tingkat signifikansi 0,05 . Temuan menunjukkan bahwa tidak ada perbedaan yang signifikan dalam pandangan responden tentang sikap guru sekolah menengah terhadap pendidikan seks berdasarkan jenis kelamin dan jenis sekolah, kecuali berdasarkan usia. Direkomendasikan antara lain bahwa; Guru harus mengajarkan aspek-aspek tertentu dari seksualitas di sekolah agar siswa terbiasa dengan harapan masyarakat tentang peran masa depan mereka sebagai Suami dan istri.
\end{abstract}




\section{INTRODUCTION}

In Nigeria society, issue of sex and sexuality are hardly openly discussed with children and adolescents. The society including parents in most cases appears to be seriously opposed to passing such information to children. This is because of the belief that such issue may make youths to be morally loosed. But in recent times, as a result of technological advancement especially in the area of Information and Communication Technology (ICT), children have on their own acquired such concealed information from the internet and this seems to have exposed some of the youth to sexual promiscuity. Experimenting the new things they are seeing over the internet appears to have resulted in increased teenage pregnancy, contacting of sex related diseases such as gonorrhea, HIVIAIDS etc. This is where the need to teach sexual education becomes eminent.

Sexuality education is an important aspect of the life of all humans; according to Toor (2012) is a lifelong process of building a strong foundation for sexual health through acquiring information and forming attitudes, beliefs and values about identity, relationship and intimacy. He stressed further that it encompasses education about reproductive health, reproductive rights, and responsibilities, sexual abstinence, and anatomy of human sex, reproduction and other aspects of human sexual behaviors. Sex education involved those education and information that involved human sexual anatomy, sexual reproduction, sexual intercourse, reproductive health, emotional relations, reproductive rights and responsibilities, abstinence, contraception, family planning, body image, sexual orientation, sexual pleasure, values, decision making, communication, dating, relationships, sexually transmitted infections (STIs) and how to avoid them, and birth control methods.

Almost all people, including children and most importantly the secondary school students deserve to know about sex education. Sex education supposed to be valued by teachers, students and parents. Incidentally, sex education seems not to be valued by the society. Azuzu (2010) observes that currently, sex education is mostly perceived as "value free". Most of the content of sex education is amorous because of the misplaced emphasis on safe sex, which tends to erode the cultural reserve of sex to married couples.

Secondary school students deserve access to necessary information and skills required to aid them in developing responsible decision about sexuality especially during adolescence, because of the urge for sexual experimentation at this stage and increased development of sexual organs. Absence of sex education gives rise to adolescent sexual activities. Imam (2009) reported that there is increased in the number of sexually transmitted infections including Acquired Immune Deficiency Syndrome (AIDS) among adolescents arising from their sexual activeness. Secondary school teachers supposed to play critical role in the teaching of sex education, but unfortunately, it appears that most secondary school teachers in Nigeria lack the skills, competences and the correct attitude toward sex education.

Ajala (2002) observed that some of the secondary school teachers who teach sex education skip topics related to reproductive system, some of the teachers feel ashamed to mention male and female reproductive organs, and some don't answer questions on male and female reproductive organs while some of them don't respond to questions related to sexuality. Ikorok (2004) suggested that for effective teaching of sex education, certain qualities are required of the teacher. The teacher should possess accurate and scientific knowledge relating to sex education in such areas like reproduction, body image, friendship, marriages, growth and development. He should be emotionally stable, honest, and accessible and should have positive attitude towards sex education. 
Nwokedi (2008) stated that sexual education for adolescents remains controversial issue in Nigeria. This statement further explains a survey conducted nationally which reveals that teachers, who ought to be the primary sexual educators for students or children play the least role in this area. School provides little or no sexual education programmes for young people. The guideline also noted that many more Nigerians are beginning to realize that if the problems of unwanted teenage pregnancy, transmission of STI such as HIVIAIDS and sexual abuse are to be effectively addressed, it is important that all people should develop accurate, rational and responsible attitudes and behaviour towards issue around sexuality.

Adolescent sexuality education is not a limited concept its sexual activities are not restricted to penetrative sex or use of contraceptives. Indeed sexual expression may include kissing, touching, fantasy, sensual and erotic behaviour. Adolescents are also concerned with developing satisfying peer relationships with members of both sexes. They show greater interest in their own individual development, their family and relationships. It is important to from explore other topics that influence their development such as body image, gender roles, and ways of expressing love and intimacy among others.

Sex education is required for adolescent to provide them positive direction, right information, which would avoid unnecessary worries and tensions. Sex education is needed for freedom from sexual dysfunctions and organic disorders, to create awareness about sexual-social issues like gender discrimination, child marriage, dowry, prostitution etc. having a programme of sex education in the schools will not be panacea for all social ills, nor will in facts necessarily be a motivation for improved behavior because adolescents have requirement to know the truth, the right answers, and factual knowledge to counteract the fantasies and half truths which they are getting from their peers.Sex education can be an important and effective way of enhancing young people's knowledge, attitudes and behaviour. There is widespread agreement that formal education should include sex education and what works has been well researched. Children and teens need good information about sex, sexual relationships, reproduction and birth control, sexually-transmitted diseases, and sexual abuse. Information is power, and in this high -risk day and age, children and teens need all the information they can get. To withhold information about sex and the possibility of sexual abuse, as well as information about reproduction and disease, puts all children at risk. The word sex seems to be seen as sacred word which should not be mentioned especially in the presence of children and youths (adolescents), the argument is based on the fact that by discussing sex, it stimulates and exposes younger ones to various sexualities which transform them to promiscuity. Today, the problems resulting from the lack of sex education to our youth are numerous; they include unwanted pregnancies, increase abortion, high rate incidence of sexually transmitted diseases and many more. All these have led to inability to concentrate, poor academic performance, deterioration of mental health of students, high rate of school dropout, and increase in illiteracy and over population. Despite the increasing sexual problems, teachers and parents are still not providing teenagers with proper knowledge of sex. Therefore, information about sex education gives an insight to people to understand the sex functions. The position of keeping silence about sex has not helped the situation but made the matters worse because cases of sexual activities engagement are reported daily.

However, it is worthy to note that many researchers have been conducting research on sex related areas such as teenage pregnancy, female genital mutilation, sexual harassment, sexual abuse. Smith 
(2000) conducted his study on safe sex and adolescents, the study found out that youth in most cases do not think of the consequences of unprotected sex when negotiating it. Luke $(20 \mathrm{II})$ in his study on sexual behaviour and use of condom among students in Nigerian schools, observed that non-challant attitude of students toward the use of condom is responsible for the fast spread of sexually transmitted diseases. But there is a dearth of literature in the area of the sex education, therefore the present researcher want to research on the area of attitude of secondary school teachers towards sex education in Osogbo LGA, Osun State.

\section{Research Questions}

a. what is the attitude of teachers toward the teaching of sex education in secondary schools in Oshogbo Local Government Area of Osun state?

b. is there significant difference in the attitude of secondary school teachers toward teaching of sex education in Osogbo Local Government Area of Osun state based on age?

c. is there significant difference in the attitude of secondary school teachers toward teaching of sex education in Osogbo Local Government Area of Osun state based on school types(public/ private)?

\section{Research Hypotheses}

The following null hypotheses were tested to guide this study;

$\mathrm{H}_{\mathrm{O}}$. There is no significant difference in the attitude of secondary school teachers toward the teaching of sex education on the basis of gender
$\mathrm{H}_{\mathrm{O} 2}$. There is no significant difference in the attitude of secondary school teachers toward the teaching of sex education on the basis of age

$\mathrm{H}_{\mathrm{O}}$. There is no significant difference in the attitude of secondary school teachers toward the teaching of sex education on the basis of school types (publicl private).

The word sex seems to be seen as sacred word which should not be mentioned especially in the presence of children and youths (adolescents), the argument is based on the fact that by discussing sex, it stimulates and exposes younger ones to various sexualities which transform them to promiscuity. Today, the problems resulting from the lack of sex education to our youth are numerous; they include unwanted pregnancies, increase abortion, high rate incidence of sexually transmitted diseases and many more. All these have led to inability to concentrate, poor academic performance, deterioration of mental health of students, high rate of school dropout, and increase in illiteracy and over population. Despite the increasing sexual problems, teachers and parents are still not providing teenagers with proper knowledge of sex. Therefore, information about sex education gives an insight to people to understand the sex functions. The position of keeping silence about sex has not helped the situation but made the matters worse because cases of sexual activities engagement are reported daily.

However, it is worthy to note that many researchers have been conducting research on sex related areas such as teenage pregnancy, female genital mutilation, sexual harassment, sexual abuse. Smith (2000) conducted his study on safe sex and adolescents, the study found out that youth in most cases do not think of the consequences of unprotected sex when negotiating it. Luke (20II) in his study on sexual behaviour and use of condom among students in 
Nigerian schools, observed that non-challant attitude of students toward the use of condom is responsible for the fast spread of sexually transmitted diseases. But there is a dearth of literature in the area of the sex education, therefore the present researcher want to research on the area of attitude of secondary school teachers towards sex education in Osogbo LGA, Osun State.

\section{METHODS}

The study is a survey research and it is descriptive in nature. This design was adopted to carry out the research because it allows researcher to use information collected from the sample respondents to generalize on the population. The descriptive research was chosen because it gives the researcher the opportunity of having direct contact with a population or sample which has features, personality, qualities, or attitudes which are relevant to the study. Clair (201I) ascertains that, a descriptive research is considered to portray accurately the characteristics of a particular individual, situation or group.The study was carried out in Osogbo Local Government Area of Osun state, Nigeria. This area is considered due to fact that the researcher is very familiar with the area.

The population for this study is all secondary schools teachers in Osogbo LGA, Osun State. According to record and report obtained at Osun State ministry of education, Osogbo, Teachers' population in the area is two thousand, three hundred and ten $(2,310)$. There are twenty five (25) secondary schools in Osogbo LGA, Osun state but in order to make this study easy and comprehensive, the researcher employed simple random sampling technique to select ten (10) secondary schools in the area (Osogbo LGA, Osun State) and twenty (20) respondents in each selected school. A number of two hundred (200) teachers serve as respondents to the study.
A well-structured research questionnaire prepared by the researcher was used in collecting data for this research, with psychometrics properties of content validity and $0.8 \mathrm{I}$ reliability index.

The instrument was administered directly to the respondents who were guided on how to complete the questionnaire items. All the copies of the isting questionnaire administered to the respondents were retrieved by the researchers at the completion of the questionnaire. The data collected in this study was analyzed with the use of descriptive statistics of frequency count and percentage.

\section{FINDINGS AND DISCUSSION}

Below are the results of the findings being collated from the response of the respondents and being summarized in tables for easy analysis.

Research Question I: What are the attitudes of secondary school teachers toward the teaching ofsex education?

Table I: Ranking of attitudes of Secondary School Teachers towards Sex Education

\begin{tabular}{|c|c|c|c|c|c|}
\hline Items & $\begin{array}{l}\text { SA } \\
(\%)\end{array}$ & $A(\%)$ & $\begin{array}{l}\text { D } \\
\text { (\%) }\end{array}$ & $\begin{array}{l}\text { SD } \\
\text { (\%) }\end{array}$ & $r$ \\
\hline $\begin{array}{l}\text { It is } \\
\text { believed } \\
\text { that it will } \\
\text { lead to } \\
\text { sexual act } \\
\text { among } \\
\text { children in } \\
\text { the society }\end{array}$ & $\begin{array}{l}101 \\
(50.5 \\
)\end{array}$ & $\begin{array}{l}81 \\
(40.5 \\
)\end{array}$ & $\begin{array}{l}10 \\
\text { (5) }\end{array}$ & $\begin{array}{l}8 \\
(4)\end{array}$ & $I^{\text {st }}$ \\
\hline $\begin{array}{l}\text { Sex } \\
\text { education } \\
\text { will expose } \\
\text { adolescents } \\
\text { to } \\
\text { premarital }\end{array}$ & $\begin{array}{l}96 \\
(48)\end{array}$ & $\begin{array}{l}79 \\
(39.5 \\
)\end{array}$ & $\begin{array}{l}13 \\
(6.5)\end{array}$ & $\begin{array}{l}12 \\
(6)\end{array}$ & $2^{\text {nd }}$ \\
\hline $\begin{array}{l}\text { Sex } \\
\text { education is } \\
\text { a taboo } \\
\text { tobe } \\
\text { discuss } \\
\text { before the } \\
\text { children }\end{array}$ & $\begin{array}{l}95 \\
(32.5 \\
)\end{array}$ & $\begin{array}{l}76 \\
(38)\end{array}$ & $\begin{array}{l}17 \\
(8.5)\end{array}$ & $\begin{array}{l}12 \\
(6)\end{array}$ & $3^{\text {rd }}$ \\
\hline
\end{tabular}




\begin{tabular}{|c|c|c|c|c|c|}
\hline $\begin{array}{l}\text { Students } \\
\text { can easily } \\
\text { be exposed } \\
\text { to sex while } \\
\text { teaching } \\
\text { them sex } \\
\text { education }\end{array}$ & $\begin{array}{l}94 \\
(47)\end{array}$ & $\begin{array}{l}79 \\
(39.5 \\
)\end{array}$ & $\begin{array}{l}14 \\
(7)\end{array}$ & $\begin{array}{l}13 \\
(6.5)\end{array}$ & $4^{\text {th }}$ \\
\hline $\begin{array}{l}\text { Sex } \\
\text { education } \\
\text { will remind } \\
\text { and induce } \\
\text { the children } \\
\text { to engage in } \\
\text { pre-marital } \\
\text { sexual acts }\end{array}$ & $\begin{array}{l}90 \\
(45)\end{array}$ & $\begin{array}{l}80 \\
(40)\end{array}$ & $\begin{array}{l}19 \\
(9.5)\end{array}$ & $\begin{array}{l}11 \\
(5.5)\end{array}$ & $5^{\text {th }}$ \\
\hline $\begin{array}{l}\text { Sex } \\
\text { education } \\
\text { will make } \\
\text { students } \\
\text { wayward }\end{array}$ & $\begin{array}{l}93 \\
(46.5 \\
)\end{array}$ & $\begin{array}{l}81 \\
(40.5 \\
)\end{array}$ & $\begin{array}{l}14 \\
(7)\end{array}$ & $\begin{array}{l}12 \\
(6)\end{array}$ & $6^{\text {th }}$ \\
\hline $\begin{array}{l}\text { Sex } \\
\text { education } \\
\text { can make } \\
\text { students to } \\
\text { feel they } \\
\text { can get } \\
\text { away with } \\
\text { their sexual } \\
\text { misconduct } \\
\text { s }\end{array}$ & $\begin{array}{l}91 \\
(54.5 \\
)\end{array}$ & $\begin{array}{l}87 \\
(43.5 \\
)\end{array}$ & $\begin{array}{l}12 \\
(6)\end{array}$ & $\begin{array}{l}10 \\
(5)\end{array}$ & $7^{\text {th }}$ \\
\hline $\begin{array}{l}\text { I am } \\
\text { skeptical } \\
\text { about the } \\
\text { usefulness } \\
\text { of sex } \\
\text { education }\end{array}$ & $\begin{array}{l}90 \\
(45)\end{array}$ & $\begin{array}{l}80 \\
(40)\end{array}$ & $\begin{array}{l}16 \\
(8)\end{array}$ & $\begin{array}{l}14 \\
(7)\end{array}$ & $8^{\text {th }}$ \\
\hline $\begin{array}{l}\text { Teachers } \\
\text { are } \\
\text { ashamed or } \\
\text { feel shy to } \\
\text { discuss sex } \\
\text { or its } \\
\text { related } \\
\text { topics with } \\
\text { secondary } \\
\text { schools } \\
\text { students }\end{array}$ & $\begin{array}{l}89 \\
(44.5 \\
)\end{array}$ & $\begin{array}{l}78 \\
(39)\end{array}$ & $\begin{array}{l}19 \\
(9.5)\end{array}$ & $\begin{array}{l}14 \\
(7)\end{array}$ & $9^{\text {th }}$ \\
\hline $\begin{array}{l}\text { Sex } \\
\text { education } \\
\text { meant for } \\
\text { married } \\
\text { people and } \\
\text { should not } \\
\text { be taught in } \\
\text { the class }\end{array}$ & $\begin{array}{l}88 \\
(44)\end{array}$ & $\begin{array}{l}76 \\
(38)\end{array}$ & $\begin{array}{l}25 \\
(12.5 \\
)\end{array}$ & $\begin{array}{l}\text { II } \\
(5.5)\end{array}$ & $\begin{array}{l}10^{t} \\
h\end{array}$ \\
\hline $\begin{array}{l}\text { Sex } \\
\text { education }\end{array}$ & 87 & 75 & 23 & $\begin{array}{l}15 \\
(7.5) \\
\end{array}$ & $\mathrm{II}_{\mathrm{h}}^{\mathrm{t}}$ \\
\hline
\end{tabular}

\begin{tabular}{|c|c|c|c|c|c|}
\hline $\begin{array}{l}\text { will create } \\
\text { more of } \\
\text { other } \\
\text { diseases } \\
\text { associated } \\
\text { with } \\
\text { sexuality } \\
\text { while taught } \\
\text { in schools }\end{array}$ & $\begin{array}{l}(43.5 \\
)\end{array}$ & $\begin{array}{l}(37.5 \\
)\end{array}$ & $\begin{array}{l}(11.5 \\
)^{2}\end{array}$ & & \\
\hline $\begin{array}{l}\text { It will } \\
\text { creates } \\
\text { awareness } \\
\text { on } \\
\text { premarital } \\
\text { sexual } \\
\text { activities } \\
\text { and other } \\
\text { related } \\
\text { issues }\end{array}$ & $\begin{array}{l}17 \\
(8.5)\end{array}$ & $\begin{array}{l}20 \\
(10)\end{array}$ & $\begin{array}{l}94 \\
(47)\end{array}$ & $\begin{array}{l}69 \\
(34.5 \\
)\end{array}$ & ${ }_{h}^{12^{t}}$ \\
\hline $\begin{array}{l}\text { There } \\
\text { should be } \\
\text { no time to } \\
\text { teach } \\
\text { children } \\
\text { about sex }\end{array}$ & $\begin{array}{l}20 \\
(10)\end{array}$ & $\begin{array}{l}14 \\
(7)\end{array}$ & $\begin{array}{l}96 \\
(48)\end{array}$ & $\begin{array}{l}70 \\
(35)\end{array}$ & ${ }_{h}^{13^{t}}$ \\
\hline $\begin{array}{l}\text { Sex } \\
\text { education } \\
\text { can } \\
\text { increase the } \\
\text { rate of } \\
\text { death as a } \\
\text { result } \\
\text { of } \\
\text { HIV/AIDS } \\
\text { infections, } \\
\text { so } \\
\text { teachers } \\
\text { should } \\
\text { develop }\end{array}$ & $\begin{array}{l}17 \\
(8.5)\end{array}$ & $\begin{array}{l}15 \\
(7.5)\end{array}$ & $\begin{array}{l}97 \\
(48.5 \\
)\end{array}$ & $\begin{array}{l}71 \\
(35.5 \\
)\end{array}$ & $\begin{array}{l}14^{\mathrm{t}} \\
\mathrm{h}\end{array}$ \\
\hline $\begin{array}{l}\text { There are } \\
\text { no } \\
\text { instructiona } \\
\text { I materials } \\
\text { to be used } \\
\text { to teaching } \\
\text { sex } \\
\text { education } \\
\text { sexual } \\
\text { activities } \\
\text { Positive } \\
\text { attitude to } \\
\text { it } \\
\text { education. }\end{array}$ & $\begin{array}{l}16 \\
(8)\end{array}$ & $\begin{array}{l}15 \\
(7.5)\end{array}$ & $\begin{array}{l}71 \\
(35.5 \\
)\end{array}$ & $\begin{array}{l}98 \\
(49)\end{array}$ & ${ }_{h}^{15^{t}}$ \\
\hline
\end{tabular}


Table above shows attitudes of secondary school teachers toward teaching of sex education in Osogbo Local Government Area of Osun state. Item II revealed that sex education will lead to sexual act among children in the society which has frequency of 182 (Strong Agree and Agree) with 91\% ranked first as the most attitude of secondary school teachers toward teaching of sex education, item 6 showed that Sex education will exposes adolescents to premarital sexual activities with frequency of 175 (Strong Agree and Agree) and percentage of $87.5 \%$ ranked second, item 2 revealed that Students can easily be exposed to sex while teaching them sex education with a frequency of 173 (Strong Agree and Agree) and percentage 86.5\% ranked third, item 14 revealed that Sex education is a taboo to be discuss before the children with a frequency of I7I(Strong Agree and Agree) and 85.5\% ranked forth has the attitude of secondary school teachers toward teaching of sex education respectively. On the other hand, Item 5 showed that there are no instructional materials to be used to teaching sex education with a frequency of 3 I (Strong Disagree and Disagree) and percentage of $15 \%$ ranked last as the attitude of secondary school teachers toward sex education in Osogbo Local Government Area of Osun state.

\section{Hypotheses Testing}

Three null hypotheses were formulated in the course of this study. Hypotheses I and 3 were tested with the use of t-test while hypothesis 2 was tested with the use of analysis of variance (ANOVA), at level of significance 0.05 . $\mathrm{H}_{\mathrm{O}}$ : There is no significant difference in the attitude of secondary school teachers toward the teaching of sex education in Osogbo Local Government Area of Osun state on the basis of gender
Table 2: t-test Analysis Showing Difference in the Attitude of Secondary School Teachers toward the Teaching of Sex Education on the Basis of Gender

\begin{tabular}{|l|l|l|l|l|l|l|l|}
\hline $\begin{array}{l}\text { Gen } \\
\text { der }\end{array}$ & $\begin{array}{l}\mathrm{N} \\
\mathrm{o}\end{array}$ & $\begin{array}{l}\text { Me } \\
\text { an }\end{array}$ & $\begin{array}{l}\text { Std. } \\
\mathrm{D}\end{array}$ & Df & $\begin{array}{l}\text { t- } \\
\text { cal }\end{array}$ & $\begin{array}{l}\text { t- } \\
2- \\
\text { tail }\end{array}$ & $\begin{array}{l}\text { Decisi } \\
\text { on }\end{array}$ \\
\hline Male & $\begin{array}{l}\text { II } \\
2\end{array}$ & $\begin{array}{l}56 . \\
55\end{array}$ & $\begin{array}{l}21 . \mathrm{I} \\
92\end{array}$ & & & & \\
\hline & & & $\begin{array}{l}19 \\
8\end{array}$ & $\begin{array}{l}0.3 \\
69\end{array}$ & $\begin{array}{l}1.9 \\
6\end{array}$ & $\mathrm{~N}$ \\
\hline $\begin{array}{l}\text { fema } \\
\text { le }\end{array}$ & 88 & $\begin{array}{l}44 . \\
62\end{array}$ & $\begin{array}{l}19.8 \\
6\end{array}$ & & & & \\
\hline
\end{tabular}

Table 2 shows that the calculated t-value is .369 while the critical t-value is 1.960 with 198 degree of freedom at level of significance 0.05 . Since the calculated $t$-value is less than the critical t-value, hypothesis Iis hereby accepted that there is no significant difference in the attitude of secondary school teachers toward sex education on the basis of gender in Osogbo Local Government Area of Osun state. $\mathbf{H o}_{2}$ : There is no significant difference in the attitude of secondary school teachers toward sex education in Osogbo Local Government Area of Osun state based on age.

Table 3: ANOVA Analysis Showing Difference in the Attitude of Secondary School Teachers toward the Teaching of Sex Education on The Basis of Age

\begin{tabular}{|l|l|l|l|l|l|l|}
\hline Source & $\begin{array}{l}\text { Sum } \\
\text { squar } \\
\text { e }\end{array}$ & $\begin{array}{l}\text { Mea } \\
\mathrm{n} \\
\text { squa } \\
\text { re }\end{array}$ & $\begin{array}{l}\mathrm{df} \\
\text { valu } \\
\mathrm{e}\end{array}$ & $\begin{array}{l}\mathrm{f}- \\
\text { cri } \\
\mathrm{t}\end{array}$ & $\begin{array}{l}\text { Decisi } \\
\text { on }\end{array}$ \\
\hline $\begin{array}{l}\text { Betwe } \\
\text { en } \\
\text { group }\end{array}$ & $\begin{array}{l}4185 . \\
7\end{array}$ & $\begin{array}{l}2092 \\
.8\end{array}$ & 2 & & & \\
\hline & & & & $\begin{array}{l}5.27 \\
4\end{array}$ & $\begin{array}{l}3.0 \\
4\end{array}$ & NS \\
\hline $\begin{array}{l}\text { Within } \\
\text { group }\end{array}$ & $\begin{array}{l}78179 \\
.1\end{array}$ & $\begin{array}{l}396 . \\
8\end{array}$ & $\begin{array}{l}19 \\
7\end{array}$ & & & \\
\hline Total & $\begin{array}{l}82364 \\
8\end{array}$ & $\begin{array}{l}2489 \\
.7\end{array}$ & $\begin{array}{l}19 \\
9\end{array}$ & & & \\
\hline
\end{tabular}

Table 3 shows that the calculated f-value is 5.274 while critical f-value is 3.04 with 2 and 197 degree of freedom 
and at level of significance 0.05 . Since the calculated $f$ value is greater than critical f-value, hypothesis 2 is hereby rejected that there is significant difference in the attitude of secondary school teachers toward sex education in Osogbo Local Government Area of Osun state on the basis of age. $\mathbf{H}_{\mathbf{0 3}}$ : There is no significant difference in the attitude of secondary school teachers toward sex education in Osogbo Local Government Area of Osun state based on school types(public/ private).

Table 4 t-test Analysis Showing Difference in the Attitude of Secondary School Teachers Toward the Teaching of Sex Education on the Basis of School Type

\begin{tabular}{|l|l|l|l|l|l|l|l|}
\hline $\begin{array}{l}\text { Gend } \\
\text { er }\end{array}$ & $\begin{array}{l}\mathrm{N} \\
\mathrm{o}\end{array}$ & $\begin{array}{l}\text { Mea } \\
\mathrm{n}\end{array}$ & $\begin{array}{l}\text { Std. } \\
\mathrm{D}\end{array}$ & Df & $\begin{array}{l}\mathrm{t}- \\
\mathrm{cal}\end{array}$ & $\begin{array}{l}\mathrm{t}- \\
2- \\
\text { tail }\end{array}$ & $\begin{array}{l}\mathrm{De} \\
\mathrm{ci} \\
\text { sio } \\
\mathrm{n}\end{array}$ \\
\hline public & $\begin{array}{l}12 \\
0\end{array}$ & $\begin{array}{l}60.6 \\
\mathrm{I}\end{array}$ & 23.9 & & & & \\
\hline & & & & $\begin{array}{l}19 \\
8\end{array}$ & $\begin{array}{l}\mathrm{I} .5 \\
5\end{array}$ & $\begin{array}{l}1.9 \\
6\end{array}$ & $\mathrm{~N}$ \\
\hline $\begin{array}{l}\text { privat } \\
\text { e }\end{array}$ & 80 & 40.9 & 18.9 & & & & \\
\hline
\end{tabular}

Table 4 shows that the calculated t-value is $1.55 \mathrm{I}$ while the critical t-value is 1.960 with 198 degree of freedom at level of significance 0.05 . Since the calculated t-value is less than the critical t-value, hypothesis 3 which stated that there is no significant difference in the attitude of secondary school teachers toward sex education in Osogbo Local Government Area of Osun state on the basis of school type is hereby accepted.

\section{Discussion}

The study investigated the attitudes of secondary school teachers toward the teaching of sex education in Osogbo Local Government Area of Osun state. Three research questions and three null hypotheses were formulated in order to find out the attitudes of secondary school teachers toward sex education.

Research questions were ranked and interpreted logically and respectively, three null hypotheses formulated for the purpose of this study were also analyzed in order manner. The null hypotheses revealed that two(I and 3 ) out of three null hypotheses formulated were accepted which indicated that there was no significant difference in the attitudes of secondary school teachers toward sex education, mean gender and school type were not determinant of the attitudes of secondary school teachers toward sex education while hypothesis number two $\left(\mathrm{Ho}_{2}\right)$ was rejected, which indicated that age can determine the attitudes of secondary schools teachers toward sex education in Osogbo Local Government Area of Osun state.

One of the reasons many teachers have lackadaisical attitude towards the teaching of sex education is as a result of the belief they have concerning it that it will lead to more sexual act among the students once they have more information about sex, likewise it is also believed that children could easily be exposed to sex while teaching sex education because it is believed that they may want to practice what they have learnt. This is made evident with the result of the findings in item II with frequency of 182 for (Strongly Agree and Agree) and $91 \%$. Also the result of the findings from item 3, which has the frequency of 178 for Strongly Agree and Agree with $98 \%$ and ranked $7^{\text {th }}$, shows that many teachers believed that sex education can make student get away with sexual misconducts because of the kind of preventive measures they might likely be exposed to while teaching them sex education. This findings agrees with those of Azuzu, (2010) observes that currently, sex education is mostly perceived as "value free", because high emphasis is being placed on safe sex, which is believed it can 
encourage children to engage in premarital sex and also help them get away with the sexual misconducts.

Many teachers in Nigeria find it difficult to talk students about sex because they feel shy to talk about such topic, for this reason the content of sex education is not well dealt with. The result of the findings of this research ascertain this statement due to the response of the respondents in item I which has the frequency of 167 (Strongly Agree and Agree) with 83.5\%. This finding agrees with those of Ajala, (2002) which observed that some of the secondary school teachers, who teach sex education, skip topic related to reproductive system because they are ashamed to call the names of the reproductive parts of the body. Which is not supposed to be so because adolescents these days are exposed to more information online which is been interpreted to them in a negative way.

Adults believed that teaching adolescents about sex education is a taboo; they believed that the information is supposed to be exposed to the married only. Most religions believed that sex is a sacred thing reserved for the married only, so teaching young ones who are not married about sex is a sin. The response of the respondent in item I4 with the frequency of I7I for Strongly Agree and Agree, shows that adults believed the myth that talking in front of children about sex is a taboo. This findings agrees with those of Siti, (2019) which observed that a good number of adults considered teaching of sex education to children a taboo.

\section{CONCLUSION}

With the result of the finings it is evident that if teachers are being equip with the right trainings and skill concerning teaching of sex education, it will help decree the rate at which adolescents dies of abortion every year due to lack of information from the right and proper source. Students tend to interact and relate more with their teachers in this dispensation because they spend more time in school than at home with their parent, also they believed more in the information they are being exposed to by their teacher. For this reason there is necessity that teachers should be equipped with the right skills so they can be bold confident about what they are teaching.

Likewise parents should be reoriented that the first socialization process is expected to start from the family, before they are being exposed to various values and information in the society this goes with the saying that, "charity begins at home". Parents should be encourage to interact and listen well to their children/wards during adolescent stage because the growth they see in their body physically and emotionally will bring so many questions they need answers to, which may prompt them to want to seek opinion from their peers. Parents should be able to be there for them before they are likely to be exposed to wrong information by their peers.

Based on the finding of the research, the following recommendations were made:-

I. Teachers should teach certain aspects of sexuality at schools so that Students will be familiar with societal expectations of their future roles as husband and wife.

2. That parent should be encouraged in teaching their children sex education since teaching might save the children from unwanted consequences that might result from lack such knowledge.

3. Teachers also should be given adequate training on sex education to equip them with able and enable materials to gain the knowledge theme in.

4. Adult citizens of Osogbo Local Government Area of Osun State should be discouraged from being shy in telling or teaching about sex 
education, since such attitude might hinder them from teaching sex education in their individual families.

5. Teacher, political and religious leaders, councilor, social health worker and village heads should create the chance to conduct sponsored seminars on sex education for students.

\section{REFERENCES}

Ajala, B.E. (2002).Sexual Behaviours of Female Undergraduates in Nigerian University: Implications for school health education and services.

Azuzu, M.C. (2003). The Nigerian health education agenda and the Catholic Response needed in its regards. A lead paper presented at National Workshop on sex education for Catholic Laiti, Enugu.

Ikorok, M.M. (2004). Value-based sexuality education in Nigerian Schools. Nigerian Journal of Health Education.

lyoke, C.A., Onah,H.E., \&Onwassigwe, C.N.(2006).Teachers Attitudes are Not An Impediment to Adolescents Sexuality Education in Enugu, Nigeria. African Journal of Reproductive Health

Naidoo, P. (200I). Risk Taking Behaviour and Health Promotion amongst Youth In respect of Reproductive Health. Journal of Psychology, I7(I), I-II.

Nwakwo, S. O. (20I4). Adolescent sexuality, Needs and counselling services in Senior Secondary School (SSS) in Kwali Abuja. Perspectives in Guidance and counselling, Edited Adegoke, A. A. And Aluede O., Benin City: Justice Jero Printing and Publishing Global.

Okafor,P.N (2010).Premarital Sex and Teenage Pregnancy among Adolescents: Counselling Implication. The Lagos Counselor

Osei, A. (2009).Within the School wall: The role of Discipline, Sexuality and the Curriculum. New York: Rutledge.
Siti, M. (2019). Importance of Sex Education from the Adolescents' Perspective: A Study in Indonesia. Open Journal for Psychological Research .

Toor, K. K. (20I2). A Study of the attitude of teachers, parents and adolescents towards sexuality education MIER Journal of Educational Studies, 2(2), I77-189 